\title{
Ticks (Acari: Ixodidae) Parasitizing Red Foxes (Vulpes vulpes) in Slovakia and New Data About Subgenus Pholeoixodes Occurrence
}

\author{
Grzegorz Karbowiak $^{1}$ (D) Michal Stanko² $\cdot$ Martina Miterpaková $^{2} \cdot$ Zuzana Hurníková $^{2} \cdot$ Bronislava Víchová $^{2}$
}

Received: 21 August 2019 / Accepted: 9 December 2019 / Published online: 25 March 2020

(c) The Author(s) 2020

\begin{abstract}
Background Distribution and biology of Pholeoixodes ticks is not very well understood. The goal of the study was to collect new data on the Pholeoixodes tick occurrence in Slovakia.

Methods Tick infestation of red foxes in the regions of Košice, Prešov, Bratislava and Žilina was studied during the period 2017-2018. Ticks were collected from the fur of animals using tweezers and identified using appropriate keys. In total, 146 red foxes (Vulpes vulpes) were investigated.

Results In total, 39 (26.7\%) of animals were found to be infected with ticks from five species. Pholeoixodes ticks were found on 13 (3.4\%) of the foxes: Ixodes hexagonus (Leach, 1815) on 5 specimens (3.4\%), in the Košice, Prešov and Žilina regions; I. crenulatus (Koch, 1844) on 8 specimens (5.5\%) in the Prešov and Bratislava regions; Ixodes ricinus (Linnaeus, 1758) collected from 25 (17.2\%) foxes in every locality; Dermacentor reticulatus (Fabricius, 1794) from 5 foxes (3.4\%) in the Košice, Prešov and Žilina regions; Haemaphysalis concinna (Koch, 1844), from 4 foxes (2.8\%) from the Košice region. Conclusions Ixodes hexagonus has been previously recorded in Slovakia. However, this is the first finding of I. crenulatus in the country. The morphological features of the I. crenulatus specimens found in Slovakia were identical to those of ticks described in Poland and descriptions given in identification keys.
\end{abstract}

Keywords Ixodes crenulatus $\cdot$ Ixodes hexagonus $\cdot$ Vulpes vulpes

\section{Introduction}

The subgenus Pholeoixodes (Schulze, 1942), includes tick species occurring in the Palaearctic, Nearctic and Neotropical Zones. They are distinguished from other ticks of the Ixodes genus by many morphological features, such as a short capitulum and thickset legs. They are also characterised by the presence of relatively short internal spurs on the coxae of the first legs, or in some cases, their complete absence. In addition, the tarsi of the first leg are stepped below Haller's organ and the genital aperture is located between the coxae 3 . While three pairs of setae can be seen on the anal plate of nymphs, five are present in adult females [14, 30, 37]. All Pholeoixodes ticks engage in a

Grzegorz Karbowiak

grzgrz@twarda.pan.pl

1 Witold Stefański Institute of Parasitology of Polish Academy of Sciences, Twarda 51/55, 00-818 Warsaw, Poland

2 Institute of Parasitology, Slovak Academy of Sciences, Hlinkova, 3, 04001 Košice, Slovakia nest-dwelling mode of feeding, residing in the nests and burrows of their hosts. Hence, Pholeoixodes specimens are only occasionally caught by flags and drags, and most of the data on their occurrence has been based on the specimens collected from hosts [30, 37].

Of the Pholeoixodes ticks, five species affecting carnivores in Europe have been described: Ixodes canisuga Johnston, 1849; Ixodes (Pholeoixodes) crenulatus Koch 1844; Ixodes (Pholeoixodes) hexagonus Leach, 1815; Ixodes (Pholeoixodes) rugicollis Schulze et Schlottke, 1929; Ixodes (Pholeoixodes) kaiseri Arthur, 1957 [13, 30, 37].

\section{Ixodes canisuga (Johnston 1849)}

Ixodes canisuga is associated with mammals which inhabit burrows. The most commonly infested species are mediumsized Mustelidae and Canidae, such as the red fox (Vulpes vulpes) and badger (Meles meles), among others [10, 35, 43]. This tick species is also a common parasite of domestic dogs and has been found on cats [25]. The known distribution of this tick ranges from Great Britain, Ireland and France in the 
West, to Austria and Germany in the East [10, 31, 39, 43], and Portugal to the south [35]. In addition, Ixodes canisuga has been observed in the countries of southern Europe, i.e., Hungary, Romania, Croatia, Serbia, Bosnia and Herzegovina, although these have only been recorded as single sightings $[9,13,16,27]$.

\section{Ixodes (Pholeoixodes) crenulatus (Koch 1844)}

Ixodes crenulatus is the second tick species to be associated with carnivores; however, infestations have also been observed in large insectivores and large rodents [30, 37]. Its documented range includes Poland, Ukraine and Romania [13, 17, 18, 26, 30, 42]. Its southernmost border runs along northern Iran, Afghanistan and Kazakhstan [14, 30, 37].

\section{Ixodes (Pholeoixodes) hexagonus (Leach, 1815)}

Ixodes hexagonus is associated with hedgehogs, Erinaceus europaeus and E. roumanicus, as main hosts and the broad spectrum of medium-sized burrow-inhabiting mammals. Apart from hedgehogs, it is commonly found on red foxes and mustelids, including the badger (Meles meles), European pine marten (Martes martes), stoat (Mustela erminea), European polecat (Mustela putorius) and occasionally the otter (Lutra lutra) $[4,7,8]$; it has also been found on large rodents, including beavers (Castor fiber) [30, 37, 39]. The distribution of I. hexagonus covers almost the whole of Europe, ranging from the British Islands and Atlantic coast on the west [31], across all the countries in the central Europe to the eastern border of Romania. The tick is common in Austria, the Czech Republic [6, 7, 39], Poland $[18,19,24,45]$, Slovakia [5, 23, 32] and Germany [10, 33, 43]. Filippova [14] did not demonstrate its occurrence to the east of the River Bug. The range extends to southern Scandinavia in the north and the Mediterranean coast in the south, where it is regarded as a rare tick species [12, 14, 37]. Isolated populations have been found in northern Africa and the Middle East [41, 42].

Fig. 1 Map of Slovakia with marked counties, where the samples were collected

\section{Ixodes (Pholeoixodes) kaiseri (Arthur, 1957)}

Ixodes kaiseri has a poorly known range. Its described occurrence covers south-eastern Europe from Romania and Moldavia, extends across southern Ukraine to Kazakhstan to the east, and towards Israel and Egypt to the south [13, 14]. Wodecka et al. [44] report the presence of Pholeoixodes females, nymphs and larvae from raccoon dogs and badgers, and these were morphologically distinguished from $I$. crenulatus and I. hexagonus. An analysis of thirty-four ITS2 sequences revealed high similarity to I. kaiseri.

\section{Ixodes (Pholeoixodes) rugicollis (Schulze et Schlottke, 1929)}

Ixodes rugicollis is rarely observed in Europe, with only isolated observations being recorded in localities in France, eastern Germany, Switzerland, Poland and Romania [8, 13, $33,37,42]$. Ticks (nymphs and adult females) were collected from dogs in the Podkarpackie voivodeship and from badgers in the Dolnośląskie voivodeship in Poland. However, no detail has been provided regarding their exact coordinates and developmental stage [38].

\section{Materials and Methods}

The present study was conducted in Slovakia during the period 2017-2018, in the regions of Košice, Prešov, Bratislava and Žilina (Fig. 1). Red foxes were legally shot during the monitoring of the effect of oral antirabies vaccination by the State Veterinary and Food Administration of the Slovak Republic. The research was conducted in compliance with the internationally required guidelines under the special permit of the Ministry of Environment of the Slovak Republic. Ectoparasites were collected from animal skin and fur by combing and using tweezers, and preserved in $70 \%$ ethanol until further study. The ticks were determined using appropriate keys to

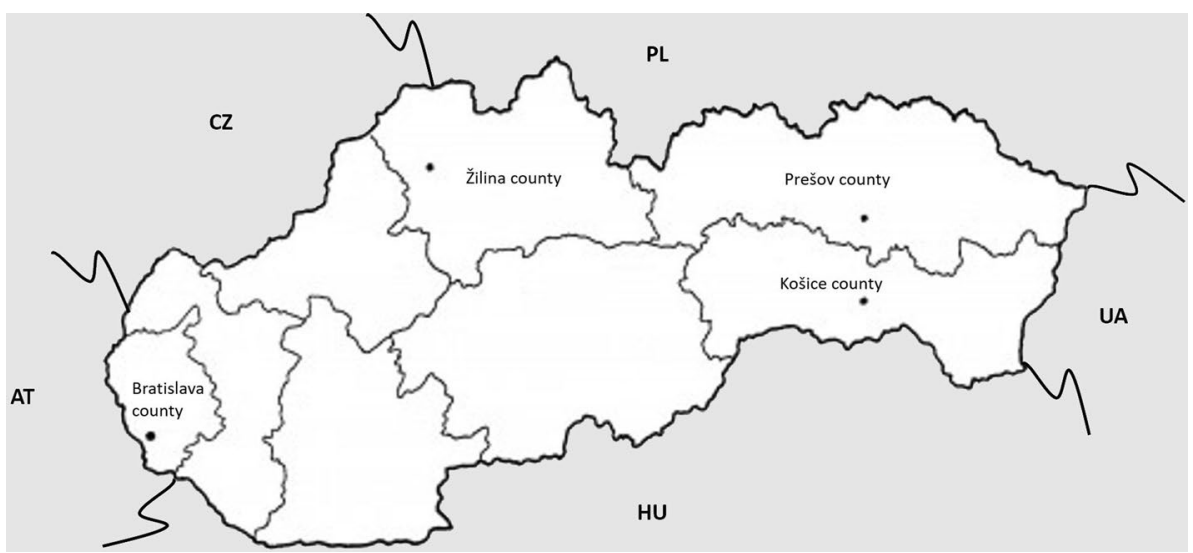


distinguish the central and east-European species by Filippova [14], Nosek and Sixl [29] and Siuda [37].

The structure of tick groups were characterised by the prevalence and intensity of infestation, the factors commonly used in the description of parasitocenoses. However, because there is often no correlation between the intensity of infestation and the incidence of parasites, the index of infection $(Z)$ is additionally used. $Z$ is calculated according to the formula $Z=(A \times B) / C^{2}$, where: $A=$ the number of parasites of the given species, $B=$ the number of foxes infested with this same parasite species, $C=$ the number of foxes examined in the sample. The index is able to prove the dominant parasite species, following the influent and accessory species in the grouping $[3,11,20]$, independent of the number of hosts and parasite population size.

\section{Results}

In total, 146 red foxes (Vulpes vulpes) were investigated; 112 from the Prešov region, 9 from the eastern part of the Košice region, 17 from the Bratislava region in western Slovakia, and 8 from the Žilina region in the central northern part of Slovakia. Ticks were found on 39 of the animals tested from the regions: 8 from Žilina, 9 from Košice, 10 from Bratislava, and 12 from Prešov. Five species of ticks were found on the foxes: Ixodes ricinus, Dermacentor reticulatus, Haemaphysalis concinna, Ixodes hexagonus and Ixodes crenulatus (Table 1).

Among them, Pholeoixodes ticks were found on 13 foxes-I. crenulatus on two foxes from Bratislava, one from Košice region and five from Prešov, I. hexagonus on one specimen from Košice region, one from Prešov and three from Žilina. There were some mixed infestations: I. rici$n u s+I$. crenulatus on single specimens from Prešov and from Košice; I. ricinus + I. hexagonus on single specimens from Košice and from Žilina; $D$. reticulatus $+I$. hexagonus on one animal from Košice. There were no mixed infestations with I. crenulatus and I. hexagonus.

The analysis of prevalence and index of infection $Z$ show that the dominant species in all localities was Ixodes rici$n u s$ - the prevalence of infestation was 5.4-66.6\%, mean $17.2 \%$; the index of infection $Z 0.44-1.40$, mean 0.76 . The influent species were $I$. hexagonus and $I$. crenulatus, the prevalence was (I. hexagonus) $0.9-37.5 \%$, mean $3.4 \%$, $Z=0.02-0.14$, mean 0.03 , and (I. crenulatus) $4.5-11.1 \%$, mean $5.5 \%, Z=0.01-0.73$, mean 0.14 , respectively. Accessory species were $H$. concinna and $D$. reticulatus. $H$. concinna was present in two localities-Košice and Bratislava, the prevalence was 11.1 and $17.6 \%$, mean $2,8 \%$, $Z=0.02$ and 0.84 respectively. $D$. reticulatus occurred in three localities-Kosice, Prešov, Bratislava, the prevalence was $0.9-17.6 \%$, mean $3.4 \%, Z=0.01-0.05$, mean 0.02 .

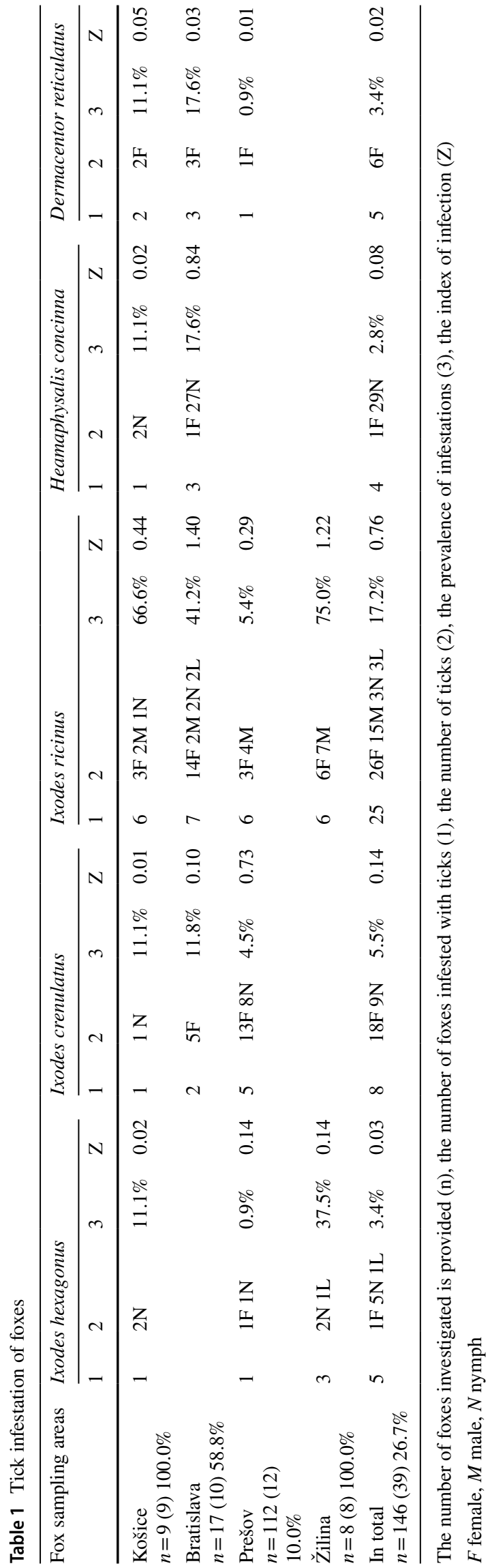


Fig. 2 A The most important distinguishing morphological features of Ixodes crenulatus female: a the auriculae size; $\mathbf{b}$ the length of coxae 1 internal spurs with blunt ending; $\mathbf{c}$ the length and size of cornua; $\mathbf{d}$ deep cervical grooves of scutum and presence of lateral grooves. B The most important distinguishing morphological features of Ixodes hexagonus female: a the auriculae size; $\mathbf{b}$ the length of coxae 1 internal spurs, with point end and the presence of coxae 2-3 external spurs; che length and size of cornua; $\mathbf{d}$ deep cervical grooves of scutum
A
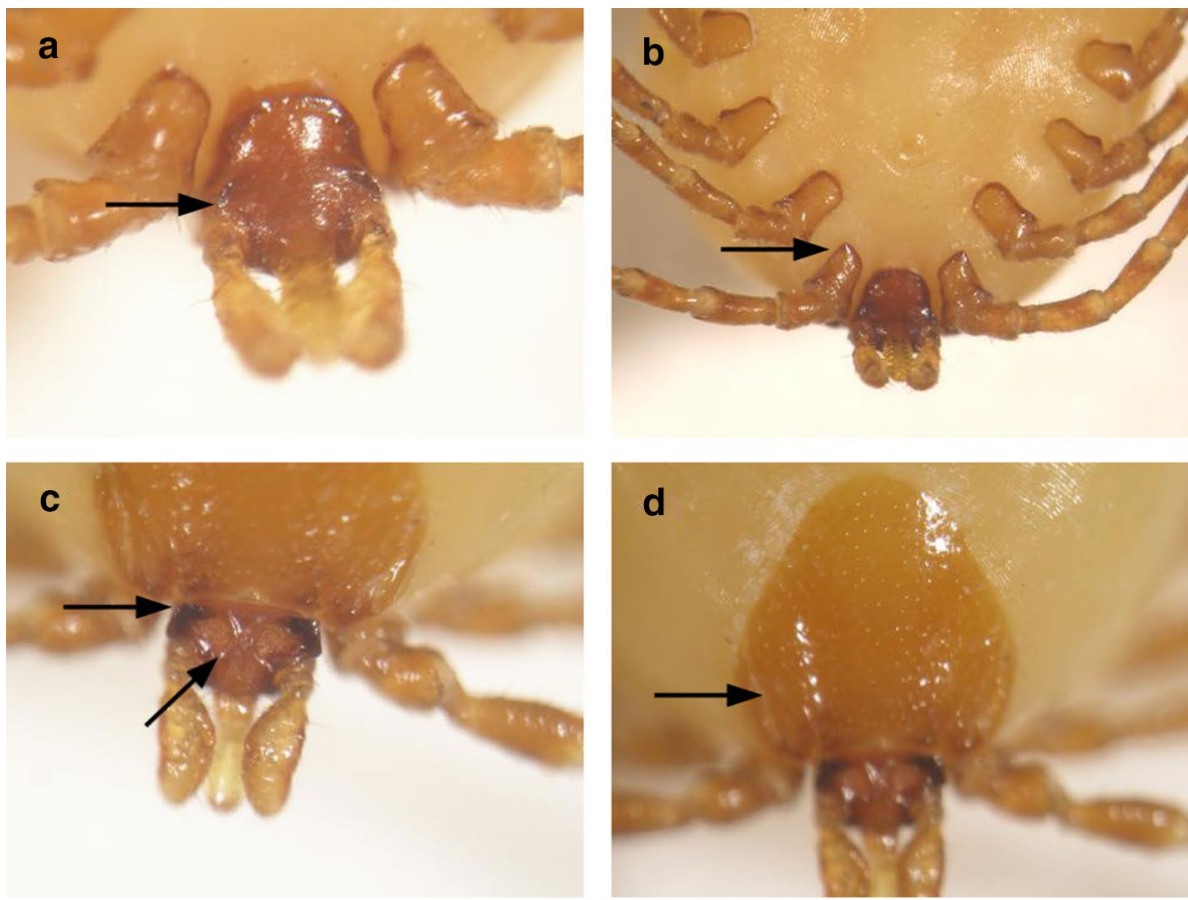

B
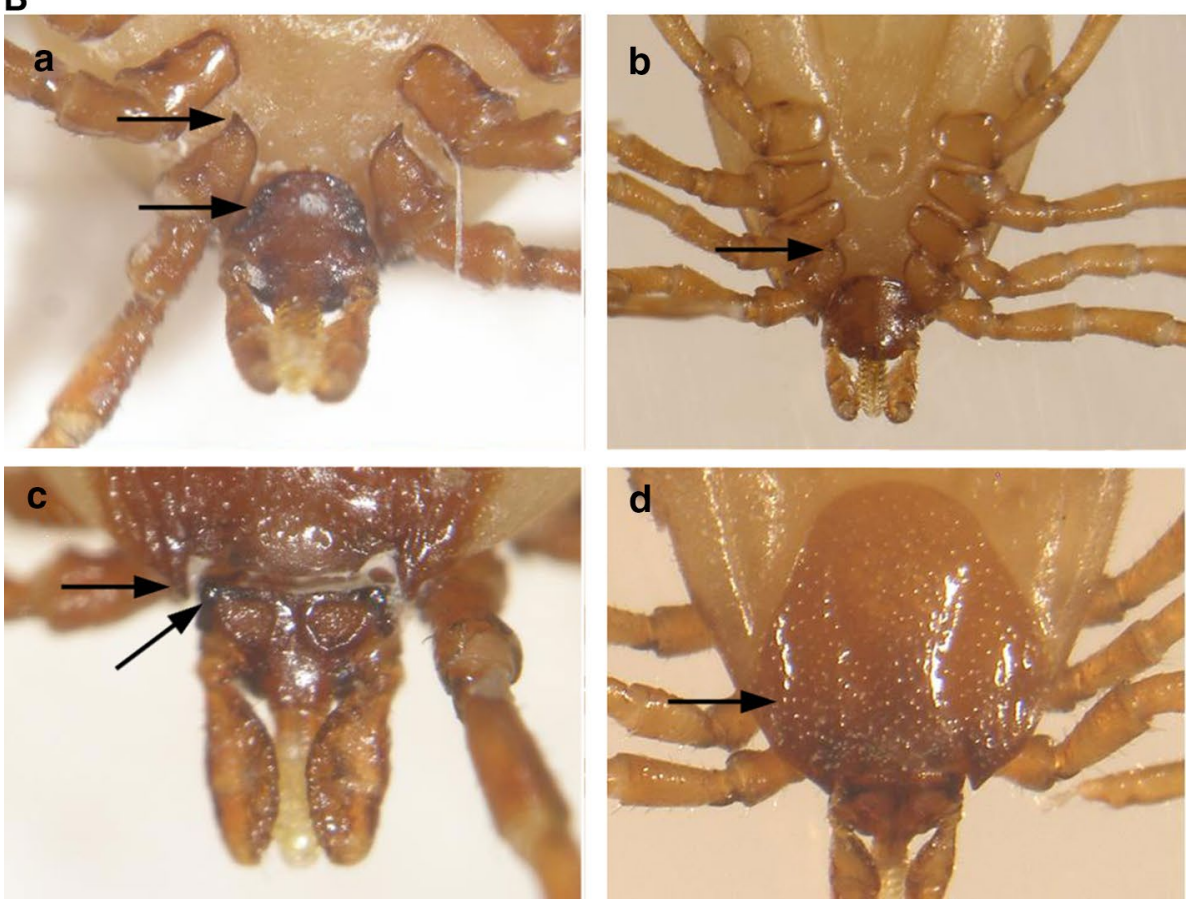

Two species of Pholeoixodes ticks were identified. These displayed the morphological features typical of the Pholeoixodes subgenus and enabled the species identification, i.e., I. hexagonus and I. cenulatus. All of these features distinguished the investigated ticks in accordance with all used determination keys, i.e., Filippova [14], Nosek and Sixl [29] and Siuda [37]. The most important features are compiled in Table 2. These are the tarsi of the first leg stepped below
Haller's organ, the genital aperture located between coxae 3 and the relatively short capitulum. The auriculae size, the length of the cornua, and the length of the coxae 1 internal spurs distinguished the males and females of these species, while the cornua length, the length of coxae 1 internal spurs, and the presence/absence of coxae 2-3 external spurs distinguished the nymphs (Fig. 2). The morphological nomenclature was used according to Estrada-Peña [12]. 


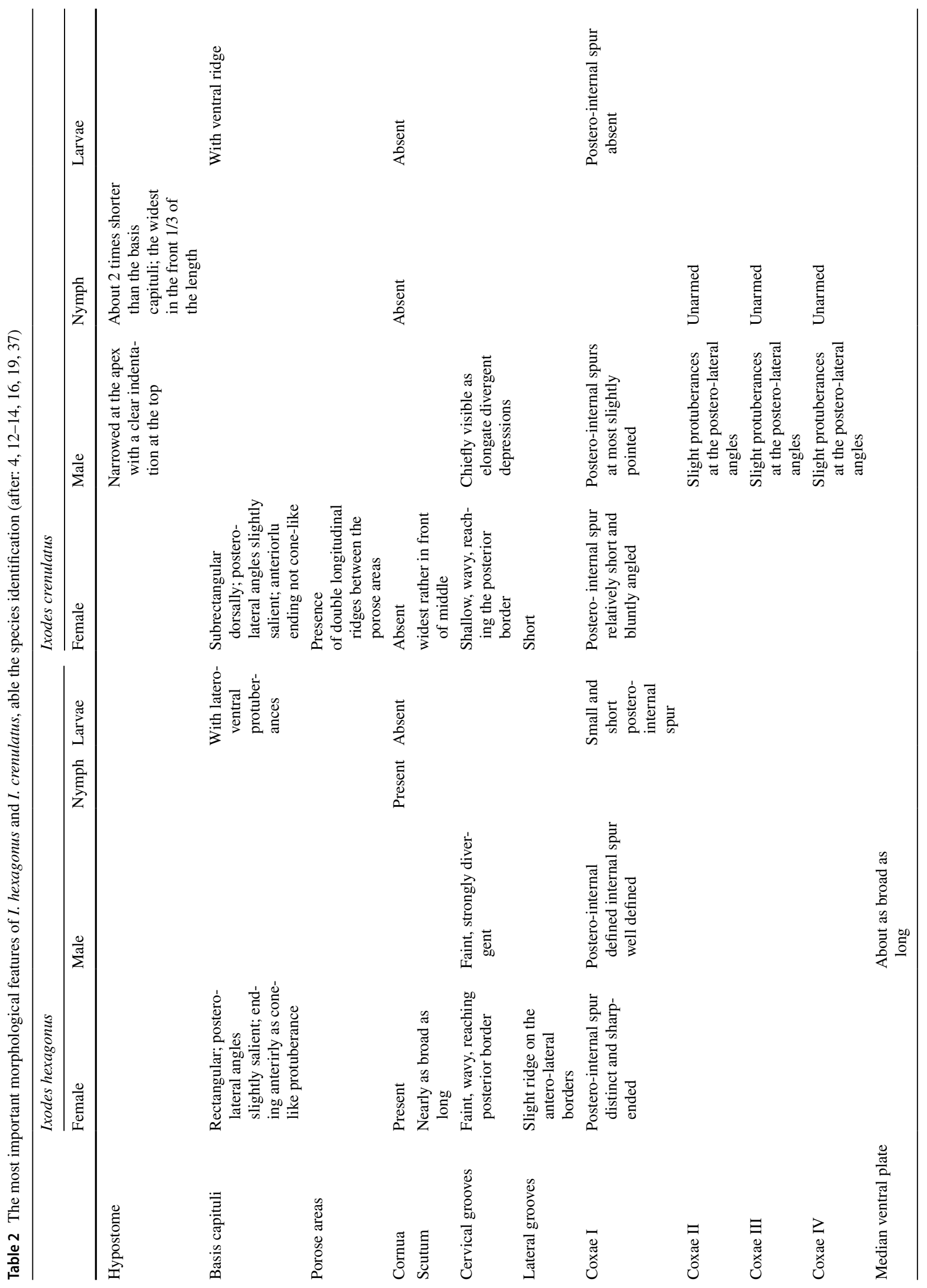




\section{Discussion}

There is the first evidence of Ixodes crenulatus in Slovakia. This species had not been recorded before the present study; however, its occurrence has previously been noted in Poland [17, 18], Czech [28] and Ukraine [1, 14]. Ixodes hexagonus has been identified in various parts of the country, including the Ondavská Highlands and Tribeč Mountain [5, 23, 28], as well as the south-eastern area [22].

The structure of tick groupings on foxes is typical for the European population of this host. The prevalence of infestation is typical and similar to values noted in the same geographic latitude. The available data in Central Europe show the infestation of foxes with I. ricinus from 17.9 to $82.2 \%$ [21, 36], with D. reticulatus from 24.5 to $27 \%$ [18, 40], I. canisuga from 4.8 to $35.3 \%$ [25, 40], I. crenulatus $2.9 \%$ [18], I. hexagonus 1.8 to $37.5 \%[18,34]$.

Index of dominance $Z$ demonstrates, that the dominant species is $I$. ricinus usually, subdominants Pholeoixodes ticks. Other tick species have the accessory character. However, the status of influent and accessory species was locally differentiated, i.e., index $Z$ shows that in Prešov, $I$. crenulatus $(Z=0.73)$ dominates and $I$. ricinus is an influent species. Near Bratislava the influent species is $H$. concinna $(Z=0.10)$, and this same species is an accessory in the Košice locality $(Z=0.02)$; however, the southern locality of Bratislava is the occurrence area of this species. Other investigated localities lie on the border of $H$. concinna occurrence [29, 37]. On all localities, D. reticulatus is the accessory species-however, its occurrence in Slovakiahas changed during last decades; previously, it was classified as a rare species [2].

A review of available literature indicates a difference of opinion regarding whether two tick species are present, i.e., Ixodes crenulatus Koch, 1844 and Ixodes canisuga Johnston, 1849, or whether they constitute a single species Ixodes crenulatus, and concur with the synonym Ixodes canisuga. New publications of Estrada-Peña [13] and Guglielmone [15] have postulated the presence of two species, based on a comprehensive review of descriptions, while authors from eastern and central Europe, notably Filippova [14], Siuda [37] and Nowak-Chmura [30], postulate that I. canisuga and $I$. crenulatus are synonymous, i.e., a single species. As mentioned above, I. crenulatus has mainly been recorded in Poland and Ukraine, while I. canisuga has typically been observed in other European countries.

Two other Pholeoixodes species that affect carnivores, I. kaiseri and I. rugicollis, were not found during the study, and have not been recorded in Slovakia previously. However, according to the literature cited above, their described occurrence range covers Slovakia, and their discovery is only a question of time. 
Acknowledgements The work was financially supported by the Research and Development Operational Program funded by the ERDF: Environmental protection against parasitozoonoses under the influence of global climate and social changes (code ITMS: 26220220116) (0.2), and projects of the Scientific Grant Agency of the Ministry of Education of the Slovak Republic and Slovak Academy of Sciences VEGA No. 2/0018/16 and No. 2/0126/16.

Authors contributions GK and MS designed the study and prepared the manuscript draft. GK made the ticks species determination. BV organised material collection and postmortem of foxes; $\mathrm{MM}$ and $\mathrm{ZH}$ participates in the material collection. All authors reviewed the manuscript and participated in the final version.

\section{Compliance with ethical standards}

Conflict of interest Authors declare no conflict of interest of any sort with anyone.

Open Access This article is licensed under a Creative Commons Attribution 4.0 International License, which permits use, sharing, adaptation, distribution and reproduction in any medium or format, as long as you give appropriate credit to the original author(s) and the source, provide a link to the Creative Commons licence, and indicate if changes were made. The images or other third party material in this article are included in the article's Creative Commons licence, unless indicated otherwise in a credit line to the material. If material is not included in the article's Creative Commons licence and your intended use is not permitted by statutory regulation or exceeds the permitted use, you will need to obtain permission directly from the copyright holder. To view a copy of this licence, visit http://creativecommons.org/licenses/by/4.0/.

\section{References}

1. Akimov IA, Nebogatkin IV (1997) Nekotorye itogi izučenâ iksodovyh kleŝej v očagah borreliozov v Ukraine. Vestn Zool 31:72-77 (in Russian)

2. Bullová E, Lukáň M, Stanko M, Pet'ko B (2009) Spatial distribution of Dermacentor reticulatus tick in Slovakia in the beginning of the 21st century. Vet Parasitol 165:357-360

3. Bush AO, Lafferty KD, Lotz JM, Shostak AW (1997) Parasitology meets ecology on its own terms: Margolis et al. revisited. J Parasitol 83:75-583

4. Černý V (1961) K diagnostike kleŝa Ixodes hexagonus Leach po ličinkam i nimfam. Zool Zh 40:184-188 (in Russian)

5. Černý V (1961) Úloha volně žijících obratlovců jako hostitelů klíšlat v pastvinném místě zaklístěni v Ondavské. Vrchovinĕ Biológia Bratislava 16:574-585 (in Czech)

6. Černý V (1972) The tick fauna of Czechoslovakia. Folia Parasitol 19:87-92

7. Chmela J, Lichard M (1971) On the development of the tick Ixodes hexagonus Leach, 1815 in the North-Moravian natural focus of tick-borne encephalitis. Folia Parasitol 18:79-83

8. Christian A (2012) Tick infestation (Ixodes) on the Eurasian Otter (Lutra lutra) - a long-term study. Soil Org 84:481-487

9. Coipan EC, Vladimirescu AF, Ciolpan O, Teodorescu I (2011) Tick species (Acari: Ixodoidea) distribution, seasonality and host associations in Romania. Travaux du Muséum National d'Histoire Naturelle «Grigore Antipa» 54:301-317

10. Cornely M, Schultz U (1992) Zur Zeckenfauna Ostdeutschlands. Angew Parasitol 33:173-183 (in German)
11. Czachorowski S (2004) Opisywanie biocenozy-zoocenologia, skrypt elektroniczny dla magistrantów (in Polish). www.uwm.edu. pl/czachor/publik/pdf-inne/zoocenozy.pdf. Accessed 2019

12. Estrada-Peña A (2004) Ticks of domestic animals in the Mediterranean region: a guide to identification of species. University of Zaragoza, Zaragoza

13. Estrada-Peña A, Mihalca AD, Petney TN (2017) Ticks of Europe and North Africa. A guide to species identification. Springer International Publishing, Cham

14. Filippova NA (1977) Iksodovye kleŝi podsem. Ixodinae. Fauna SSSR. Paukoobraznyje T 4 (4). Izdavatel'stvo Nauka, Leningrad, USSR. (in Russian)

15. Guglielmone AA, Robbins RG, Apanaskevich DA, Petney TN, Estrada-Peña A, Horak IG (2014) The hard ticks of the world (Acari: Ixodida: Ixodidae). Springer, Dordrecht

16. Hornok S, Sándor AD, Beck R, Farkas R, Beati L, Kontschán J, Takács N, Földvári G, Silaghi C, Meyer-Kayser E, Hodžić A, Tomanović S, Abdullah S, Wall R, Estrada-Peña A, Duscher GG, Plantard O (2017) Contributions to the phylogeny of Ixodes (Pholeoixodes) canisuga, I. (Ph.) kaiseri, I. (Ph.) hexagonus and a simple pictorial key for the identification of their females. Parasit Vectors 10:545

17. Karbowiak G, Nowak-Chmura M, Szewczyk T, Werszko J, Siuda K (2017) Występowanie kleszczy z podrodzaju Pholeoixodes w Polsce w pierwszej dekadzie XXI wieku. In: Buczek A, Błaszak $\mathrm{Cz}$ (eds) Stawonogi w środowisku miejskim i podmiejskim. Koliber, Lublin, pp 69-81

18. Karbowiak G, Szewczyk T, Werszko J (2016) Ectoparasites of carnivores in north-eastern Poland. Ann Parasitol 62(suppl.): 184

19. Kilar P (2011) Ticks attacking domestic dogs in the area of the Rymanów district, Subcarpathian province, Poland. Wiad Parazytol 57:189-191

20. Kisielewska K (1970) Ecological organization of intestinal helminth groupings in Clethrionomys glareolus (Schreb.) (Rodentia). I. Structure and seasonal dynamics of helminth groupings in a host population in the Białowieża Park. Acta Parasitol Pol 18:121-147

21. Kočišová A, Lazar P, Letková V, Čurlík J, Goldová M (2006) Ectoparasitic species from red foxes (Vulpes vulpes) in East Slovakia. Vet Arhiv 76(Suppl.):S59-S63

22. Kožuch O, Grešíková M, Nosek J, Lichard M, Sekeyová M (1967) The role of small rodents and hedgehogs in natural focus of tickborne encephalitis. Bull World Health Org 36(S.1):61-66

23. Křivanec K, Kopecký J, Tomková E, Grubhoffer L (1988) Isolation of the virus from the tick Ixodes hexagonus. Folia Parasitol $35: 273-276$

24. Król N, Obiegala A, Pfeffer M, Lonc E, Kiewra D (2016) Detection of selected pathogens in ticks collected from cats and dogs in the Wrocław Agglomeration, South-West Poland. Parasite Vector 9:351

25. Liebisch A, Walter G (1986) Untersuchungen von Zecken bei Haus- und Wildtieren in Deutschland: Zum Vorkommen und zur Biologie der Igelzecke (Ixodes hexagonus) und der Fuchszecke (Ixodes canisuga). Dtsch Tierarztl Wochenschr 9:377-464 (in German)

26. Michalik J, Sikora B, Górecki G, Wierzbicka A, Wodecka B (2010) Fall-winter infestation of red foxes (Vulpes vulpes) with ixodid ticks in west-central Poland. In: Buczek A, Błaszak Cz (eds) Stawonogi. Ekologiczne i patologiczne aspekty układu pasożyt-żywiciel, Akapit, Lublin, pp 49-55 (in Polish)

27. Mihalca AD, Dumitrache MO, Magdaş C, Gherman CM, Domşa C, Mircean V, Ghira IV, Pocora V, Ionescu DT, Sikó Barabási S, Cozma V, Sándor AD (2012) Synopsis of the hard ticks (Acari: Ixodidae) of Romania with update on host associations and geographical distribution. Exp Appl Acarol 58:183-206 
28. Nosek J, Grulich I (1967) The relationship between the tick-borne encephalitis virus and the ticks and mammals of the Tribeč mountain range. Bull World Health Org 36(S.1):31-47

29. Nosek J, Sixl W (1972) Central-European ticks (Ixodoidea). Mitt Abt Zool Landesmus Joanneum 1:61-92

30. Nowak-Chmura M (2013) Fauna kleszczy (Ixodida) Europy Środkowej. Wydawnictwo Naukowe Uniwersytetu Pedagogicznego, Kraków (in Polish)

31. Ogden NH, Cripps P, Davison CC, Owen G, Parry JM, Timms BJ, Forbes AB (2000) The ixodid tick species attaching to domestic dogs and cats in Great Britain and Ireland. Med Vet Entomol 14:332-338

32. Pawełczyk O, Asman M, Jakubas-Zawalska J, Jankowski T, Solarz K (2015) Ixodes hexagonus as a potential reservoir of Anaplasma phagocytophilum and Babesia microti - the preliminary studies. In: Proceedings, 17th International Symposium Parasitic and allergic arthropods-medical and sanitarny significance. 9-11 June 2015, Janowiec nad Wisła. Koliber, Lublin, p 74.

33. Petney TN, Pfäffle MP, Skuballa JD (2012) An annotated checklist of the ticks (Acari: Ixodida) of Germany. Syst Appl Acarol 17:115-170

34. Sándor AD, D'Amico G, Gherman CM, Dumitrache MO, Domşa C, Mihalca AD (2017) Mesocarnivores and macroparasites: altitude and land use predict the ticks occurring on red foxes (Vulpes vulpes). Parasite Vector 10:173

35. Santos-Silva MM, Beati L, Santos AS, De Sousa R, Núncio MS, Melo P, Santos-Reis M, Fonseca C, Formosinho P, Vilela C, Bacellar F (2011) The hard-tick fauna of mainland Portugal (Acari: Ixodidae): an update on geographical distribution and known associations with hosts and pathogens. Exp Appl Acarol 55:85-121

36. Schöffel I, Schein E, Wittstadt U, Hentsche J (1991) Zur Parasitenfauna des Rotfuchses in Berlin (West). Berl Münch Tierärztl Wschr 104:153-157
37. Siuda K (1993) Kleszcze Polski (Acari: Ixodida) II. Systematyka i rozmieszczenie. Polskie Towarzystwo Parazytologiczne, Warszawa

38. Siuda K, Nowak M, Gierczak M (2010) Confirmation of occurrence of Ixodes (Pholeoixodes) rugicollis Schulze et Schlottke, 1929 (Acari: Ixodidae) in Poland, including the morphological description and diagnostic features of this species. Wiad Parazytol 56:77-80

39. Sixl W, Nosek J (1972) Zur Medizinische Bedeutung der Zecken Österreichs. Mitt Abt Zool Landesmus Joanneum 1:29-50 (in German)

40. Sréter T, Széll Z, Varga I (2003) Ectoparasite infestations of red foxes (Vulpes vulpes) in Hungary. Vet Parasitol 115:349-354

41. Tavassoli M, Mohamadi E (2015) First report of Ixodes (Pholeoixodes) hexagonus on chukar (Alectores chukar) in Northwest of Iran and it's public health importance. Persian J Acarol 4:205-211

42. Vladimirescu AL, Coipan EC (2010) Căpuşele (Acari: Ixodidae) vectori pentru agenţii patogeni. Ars Docendi, Bucharest (in Romanian)

43. Walter G, Kock D, Liebisch A (1986) Beitrag zur Zecken-Fauna der Bundesrepublik Deutschland (Arachnida: Acarina: Ixodidae). Senckenberg Biol 67:199-206

44. Wodecka B, Michalik J, Lane RS, Nowak-Chmura M, Wierzbicka A (2016) Differential associations of Borrelia species with European badgers (Meles meles) and raccoon dogs (Nyctereutes procyonoides) in western Poland. Ticks Tick-Borne Dis 7:1010-1016

45. Zajkowska P, Nowak-Chmura M, Siuda K (2015) Kleszcze (Acari, Ixodida) atakujące psy domowe na terenie województwa Małopolskiego. In: Buczek A, Błaszak Cz (eds) Stawonogi we współczesnym świecie. Koliber, Lublin, pp 97-99

Publisher's Note Springer Nature remains neutral with regard to jurisdictional claims in published maps and institutional affiliations. 